\title{
Contemporary sites of
} contemplation: contemplative nature of the aesthetic experience of natural and transformed landscape in Roden Crater by James Turrell and Lucid Stead by Philip K. Smith

\author{
Nadia Issa \\ (Faculty of Media Art; Academy of Fine Arts in Warsaw)
}

Abstract:

The aim of this paper is to offer an interpretation of two contemporary art works: James Turrell's Roden Crater and Philip K. Smith's Lucid Stead. They are seen as projects that may be qualified as examples of art based on the artists' playing with light. The claim being that one of the factors that engenders a contemplative attitude on behalf of the beholder is the presence of light in relation to the artwork's structure.

Key words:

The following analysis of Roden Crater by James Turrell and Lucid Stead by Philip $\mathrm{K}$. Smith will first and foremost make an attempt at defining the notion of "contemplation" with respect to what may be designated as contemporary sites of landscape contemplation, where both natural and transformed landscapes are involved. Here, the sites in question are selected works created by the aforementioned artists (i.e., Roden Crater and Lucid Stead), which in view of their target locations, visual qualities, spatial symbolism, and mystical-symbolic content may be approached and examined in that very context. I will also be interested in the viewer's direct visual 
and aesthetic experience of the landscape and the works, as this is expected to prove helpful in the attempt to formulate a definition of contemplation.

Contemplation may be described as a kind of extraordinary consciousness, gratitude for the gift of life, apprehension of our place in the universe, but also solitude which leads to enlightenment, to a communion with substance which eludes human experience. "For in contemplation we know by 'unknowing.' Or, better, we know beyond all knowing or 'unknowing"' (Merton 1972, 1-2). It is indefinableaspiring for an experience of transcendence or mysticism. "Contemplation is the highest expression of man's intellectual and spiritual life. It is that life itself, fully awake, fully active, fully aware that it is alive. It is spiritual wonder. It is spontaneous awe at the sacredness of life, of being" (Merton 1972, 1). Contemplation is perceived as a higher form of spirituality and, going further, may constitute a domain of prophets or messiahs. Lonely wandering results in Abraham's revelation. Jesus spends 44 days alone in the desert. Mohammed stays in the Cave of Hira near Mecca, devoted to contemplation. That is also where one night he experiences his first revelation that marks the beginning of his prophetic mission (Chojnacki 2008). It may be stressed at this point that contemplation means an individual experience one goes through in solitude, which considerably hampers the classification or naming of the emotions and feelings that accompany it, thus precluding an examination of contemplation as a collective or communal experience. Can works such as Roden Crater by James Turrell and Lucid Stead by Philip K. Smith be therefore called contemporary sites of contemplation? Does the fact that they are to be found in locations with particular visual features bring us closer to an aesthetic, perhaps even spiritual experience of landscape, or is the opposite the case, that is, do we become more remote and the experience more distant? Finally, can the experience of landscape be a contemplative one?

James Turrell is an American artist born in 1943 for whom space and light have been the chief area of artistic exploration. Roden Crater is one of the best-known works of the artist, in whose own opinion it is his life's foremost achievement. Since 1978 until the present day, the artist has been working on a kind of observatory built in the Arizona desert, where each viewer can use specially designed apertures in the roof and walls to observe the sky, natural weather phenomena, and the cyclicity of nature. Spectators are also able to see the changes of Earth's position with regard to the Sun, and thus "contemplate" the variation of the times of the day and the seasons (Sokolewski 2011, 173). To Turrell, space, light, and color temperatures of the latter are vehicles of mystical content and as such constitute an integral component of his works. The artist is also deeply respectful of the natural landscape of the Arizona desert. In my opinion, he manages to extract the essence and character from that space without destroying it, whilst underscoring its qualities, symbolism, and rhythm by creating a cultural landscape within the natural one. The symbols in Roden Crater derive not only from the iconography of Christian 
mysticism but draw also on other religions and mythologies. After all, the observatory stands in the desert, which epitomizes a boundless expanse, infinity, lonely human wandering in search of the Absolute. It is an allegorical place of purification and meditation encountered in most belief systems. In this context, the desert may be viewed as a geographical location as well as symbolic of a state of mind, as contemplation involves silence and observation (Chojnacki 2008). The sensation of immobility, quiet, and emptiness can be experienced in the desert as a geographical location, where distinctive natural features and the relationship between the human and the surrounding space facilitate and enable contemplation. In this context, the desert is an allegory for a void, boundlessness, of existence beyond time in unity with nature, whereby the notional desert becomes a symbol of transcendence. The visual aspect of the desert as a landscape also fosters such sensations. Its vastness, possible mirages, and alternations of temperature may be treated as metaphors for spiritual states. Both the symbol and the actual place have, in my opinion, positive connotations drawing on the experience of emptiness, which is synonymous with a higher level of spiritual development in Zen philosophy and art. Here, the experience of emptiness is a value, a synonym of purification and rebirth, something that does not necessarily have to be filled in order to feel happiness. This approach to emptiness owes to the ideological difference in Zen philosophy and art, which a person such as myself, brought up largely in the Roman Catholic tradition, might not fully comprehend. James Turrell, on the other hand, was raised in the Protestant tradition (his parents were Quakers). Certain values preached in the Quaker doctrine-which I will briefly discuss in the context of the work-may be considered indications that the choice of the desert as a location for the piece was thoroughly deliberate. This is because Quakers believed in the divine, supernatural inner light found in the heart of every human being. At the same time, light is Turrell's principal means of artistic expression and the main axis of his works. In Roden Crater, natural light penetrating into the observatory cocreates it and becomes an integral part of it; this may be interpreted as the artist's consent and surrender to the power of light that has its source in the Absolute, an expression of humility towards the Creator without whom the work would possess no raison d'être and never become a totality. In the experience of that light lies the essence of aesthetic values which in Turrell's oeuvre approach metaphysical experience. Paulina Tendera seems to point to a similar relationship in her commentary on the writings of St. Thomas Aquinas: "Apart from a cognitive dimension, supreme beauty harbours a mystical sense which transcends reason (expressed in the very notion of claritas). A person who experiences such beauty is a holy one. [...] In that experience, God is revealed to the human through mystical contemplation, filling the latter with knowledge. [...] It is not only an act of cognition, but an act of love as well" (Tendera 2013, 123). 
It may be noted that in earlier works the artist employed artificial light (e.g., in the famed Twilight Arch). It is there in Roden Crater as well, yet it performs a more pragmatic, utilitarian function, and therefore I do not consider it a vehicle of mystical substance. Still, Roden Crater betrays a change in the artist's perception as he departs from the mimetic notions of art in favor of the mystical and contemplative aspect, where an artwork becomes a window to the world and an integral part of the world, something which is very remote from any institutional understanding of art. One thus perceives a work and simultaneously experiences the space in which the work has been situated. The contemplative nature of aesthetic experience becomes a concurrent experience of the work and the landscape, thanks to which the former becomes an integral component of the space. As Leszek Sosnowski states, "in Pythagoras and Pythagoreans, ... contemplation of art is linked to contemplation of nature and cosmos, while contemplation of the order in celestial phenomena edifies the individual" (Sosnowski 2003, 2).

As can be seen, the Pythagorean notion of contemplation of art sets out from the contemplation of landscape as a value. Thus, natural landscape represents a superior value and, in a sense, a prototype for the artist. Using the symbolism of the circle as the architectural basis for his structure, Turrell draws on the cosmological order and therefore on nature as the aforesaid prototype, because the circle is a perfect figure, a symbol of the divine sphere, the sky, a reflection of the ideal, eternal motion (Kopaliński 1990). The possibility of contemplating the sky that the viewers are offered is associated with the artist's quest for transcendence and his attempt to make the experience available to the audience. "The symbol of sky denotes inexhaustibility, boundlessness, a general order, which encompasses cosmic, ethical or political order as well" (Burszta 1998, 118).

The immediacy of contact with God in which Quakers believe means that there is no need to appoint any intermediaries (priests) in the community, or to erect buildings dedicated strictly to sacred purposes (churches). Raised in such a tradition, the artist makes Roden Crater a shared space for the adherents of any religion or worldview, a space whose nature fluctuates between the sacred and the profane. The dominant feature in that space are stairs, which manage to create an illusion of a "stairway to heaven" (as the viewer ascending them approaches the sky), a mystical "celestial gate." In the context of the entire work, the stairs are a metaphorical symbol of the human journey towards light, the Absolute, or the Platonian realm of ideas. The combination of light-as a universal symbol of divinity-and the structural characteristics of Roden Crater, which draw on sacred architecture of many religions and the spatial arrangement of places of prayer across the world, warrants calling Turrell's piece a contemporary site of contemplation. Additionally, the experience of the work in the context of the desert landscape is contemplative, as "contemplative art ... teaches one how to engage in a great, relevant, and pure experience" (Filipowska 1997, 151). 
Philip K. Smith is an American artist of the younger generation, whose preferred idiom is "light art."1 Most of his works to date appear to make references to, and even draw direct visual inspiration from, the oeuvre of James Turrell and Dan Flavin. In Smith's installations, as well as in the majority of the pieces created by the latter artists, artificial, dissipated light provides the principal building block.

Made in 2013, Lucid Stead is an altogether different piece, though one cannot help noting certain similarities with Turrell's Roden Crater, as they share symbolic references of the location in which they are to be found-that is, in the allegoryladen surroundings of the desert. As for the work itself, Lucid Stead is an erstwhile, 70-year-old dwelling in Joshua Tree National Park, in the transition zone between the Mojave and Colorado Deserts in southern California, which Smith subjected to artistic transformation. The fundaments and the proportions of the house were retained, but most of the walls were covered with mirrors which reflect the boundless landscape around. At night, the mirror panels in which the artist installed LED lights shine with a surreal, colorful artificial light (Smith 2017). The perception of the work will change depending on the time of day, and the piece responds to the phenomena and rhythms of nature, transporting the viewer into a sphere where time is differently construed. According to Gadamer, a work of art is similarly determined by its own temporal structure rather than by the quantifiable duration of its existence through time (Gadamer 1986). In this case, the time of the work becomes the time of the spectator, as it were. Meanwhile, the desert landscape imposes a non-linear time in which the work is to be seen and viewed. Much like Mircea Eliade, Gadamer discerns two types of temporal experience: pragmatic and festive. Pragmatic time is a linear one, associated with action, with the performance of specific activities. Thus understood, time is not experienced in its own right, but as something that has to be "spent." In contrast, festive time is fulfilled and autonomous, as due to the nature of its solemn character, "it is arrested itself and encourages that temporal tarrying of the human" (Sosnowski $2003,6)$. It may be noted that the nature of experience of festive time is in fact an experience of landscape. It is impossible to engage in the latter without halting in one's tracks and thus without a metaphorical halting of linear time. Festive time, being identical with the time of exposure to and encounter with a work of art or landscape, is inherently contemplative, determining a contemplative sensation of landscape (a sense of transcendence), where one exists outside time and in unity with it in the course of the experience. Through contemplative artwork, the viewer may-for a brief time-experience unity with the universe, feel a part of a greater whole. The mirror-laid Lucid Stead promotes the experience, as the piece appears to blend tangibly into the surrounding space, thereby enhancing the sense of unity with the landscape. The mirror-induced abstraction enables us to see that which

1 Here, light art is taken to mean the kind of artistic utterance where light is the main or the only medium of artistic expression. 
goes beyond the world of material phenomena. Thanks to the mirrors, the house is transposed from the utilitarian sphere of the real into the symbolic realm, where the now metaphorical home becomes an integral part of the space, without disrupting the natural landscape. "Home ... is a symbol of order, harmonious cosmic alignment, the navel of the world, the Universe: the roof is the sky, the walls are the Earth, the windows are gods" (Kopaliński 1990, 206-209). Thus, the house of mirrors becomes a site of contemplation of nature and the space around it, with which it is in consonance. At night, the house changes into an artistic installation, the windows glow with alternating colors of the chromatic spectrum. Given that-as Kant (2017) claimed-nature is sublime wherever it conveys the idea of their infinity, I find the less-than-spectacular use of artificial light in Lucid Stead to be an element which represents a contradiction of sorts to the purity of composition, construction and concept of the work that is seen during the day. For this reason, the "diurnal" variant of Lucid Stead may be legitimately considered a contemporary site of contemplation, whereas the "nocturnal" version should be situated among Smith's earlier works, which should not be classified as such. The artist himself corroborates the inference that we are dealing with a site of contemplation, stating that "Lucid Stead is about tapping into the desert, into the pace of change, and it's about responding to the quiet of the place. Ultimately, in that quiet, the project begins to unfold. It's really about four ideas: light and shadow, reflected light, projected light, and change" (Smith 2017). In this understanding, contemplation may become a cure to Blaise Pascal's distraction, the perennial dissipation of attention and proclivity to forget about important things. This notion of contemplation is, I feel, most apt with respect to that work.

The monumental works of these artists help one feel the rhythm of changes in nature. The temporal structure of their work is determined by the time at which the landscape is perceived and contemplated. The experience of landscape can be contemplative in this case, "as one can speak of transition from being with respect to landscape to being in the landscape" (Frydryczak 2006, 116). The tremendous respect that the artists have for natural light and their efforts to accentuate its qualities make one aware of its symbolic significance in the world of nature and elevate it to the rank of a superior element in the contemplative experience of landscape. "The human still entertains a conviction forged over the course of centuries, namely that light is a sign of beauty, truth, oneness and perfection, a close, kindred element recognized as similar by the alike" (Tendera and Rubiś 2017, 48).

\section{References:}

Burszta, Wojciech J. 1998. Antropologia kultury [Anthropology of Culture]. Poznań: Zysk i S-ka. Chojnacki, Jerzy. 2008. "Samotność i religia" ["Solitude and Religion"]. http://www.polskieradio.pl/37/228/ Artykul/182407,Samotnosc-i-religia-J-Chojnacki. 
Filipowska, Krystyna. 1997. "Piękno a kontemplacja" ["Beauty and Contemplation"]. Śląskie Studia Historyczno-Teologiczne 30: 151-54.

Frydryczak, Beata. 2006. "Chwila: estetyczne doznanie czasu w przyrodzie" ["A Moment: Aesthetic Experience of Time in Nature"]. Dyskurs 9: 115-26.

Gadamer, Hans-Georg. 1986. "The Relevance of the Beautiful." In The Relevance of the Beautiful and Other Essays, translated by Robert Bernasconi, 3-53. Cambridge: Cambridge University Press.

Kant, Immanuel. 2017. Critique of the Power of Judgment. Translated and edited by Paul Guyer. Cambridge: Cambridge University Press.

Kopaliński, Władysław. 1990. Stownik Symboli [A Dictionary of Symbo/s]. Warsaw: Wiedza Powszechna Merton, Thomas. 1972. New Seeds of Contemplation. New York: New Directions.

Smith, Philip. 2017. "Amazing see-thru cabin built in California." https://www.youtube.com/watch?v=5rB5K _ SS67w.

Sokolewski, Rafał. 2011. "Metafizyka i synteza w sztuce współczesnej na przykładzie interpretacji dzieł Boba Wilsona, Billa Violi i James Turrell" ["Metaphysics and Synthesis in Contemporary Art—An Interpretation of Bob Wilson's, Bill Viola's, and James Turrell's Works"]. Estetyka i krytyka 20 (1): 167-78.

Sosnowski, Leszek. 2003. "Sztuka jako świętowanie" ["Art as Celebration"]. Estetyka i krytyka 5 (2): 90-105.

Tendera, Paulina. 2013. Od filozofii światta do sztuki światta [From the Philosophy of Light to the Art of Light]. Kraków: Nowa Strona.

Tendera, Paulina and Wojciech Rubiś. 2017. Nowe Światto [A New Light]. Kraków: Nowa Strona. 